\title{
Implications of Thomas Aquinas Philosophy on Contemporary Education in Kenya; A Classical Perspective
}

\author{
Khisa Alfred Simiyu ${ }^{1 *}$ Elvis Kauka Omondi ${ }^{2}$, Werunga Khisa Stephen ${ }^{3}$, William Kosgey ${ }^{4}$ \\ ${ }^{1,2}$ Department of Educational Foundations Masinde Muliro University of Science and Technology, Kenya \\ ${ }^{3}$ Department of Education Management Kibabii University, P.O Box 1699-50200, Kenya \\ ${ }^{4}$ Department of Education Foundations Moi University, Kenya \\ *Corresponding author
}

\begin{abstract}
The overemphasis of human capital for addressing societal needs has driven education systems globally to reorient education systems towards empowering the young with vital competencies for suitability in the job market. In Kenya, such an approach has led to overemphasis of grades, thus void of Values for societal change. However, other approaches like social change perspective that advocates for the transformation of the person for societal change prioritizes the "common good" as vital element for change. In addition, it allows state and religious organizations to influence education curriculum, aims and objectives for societal change. This study critically examines the salient features of Thomas Aquinas' Theory of education and establishes whether Thomas Aquinas' philosophical ideas can facilitate the realization of responsible citizens in Kenya.. The study recommends for a multidimensional approach in handling discipline issues, curriculum formulation and implementation and finally embracing a thomistic tradition for reforming education in Kenya for holistic training.
\end{abstract}

Keywords: Thomas Aquinas, classicism, Education and Training, Implications

\section{INTRODUCTION}

A ccording to Doyle (2007) the Second Vatican Council of 1965 adopted a Thomistic approach in addressing social upheavals in the church and society at large by emphasizing a moral training and intellectual training in virtues. Towards a responsible citizenry, an education system that reflects on infinite being in relation to the existence of the self has always promoted mutuality and coexistence.

In his encyclical letter Aeternis Patris (1879), Pope Leo XIII acknowledged the great influence of errors and the difference in times and the need to re-position Christian faith in reason. Other scholars who have contemplated on Thomistic thought include Jacques Maritain, Etienne Gilson and Bernard Lonergan. Maritain grounded in Thomistic thought promoted an integral humanism that could blend the best that philosophy, science, politics and Christian revelation could offer. In the light of Thomism, Maritain identified misconceptions in education created as a result of the absence of the Christian idea of man, an overemphasis on exaggerated optimism about the direct and development of intellect (intellectualism) and will (voluntarism).On the other hand, Gilson argued that the key to understanding the intellectual contributions of Aquinas are grounded in the distinction between essence and existence. This is a justification of the relevance of classical metaphysics in addressing faith and reason. Lastly, Lonergan's cognitional theory identifies an epistemological orientation grounded in the Knower "I" and the principle of intentionality. Lonergan provides a transition from classicism to historical mindedness (Liddy, 2013).

In his encyclical letter, Fides et Ratio (1998) John Paul II reminds the Faithfull that the upcoming millennium with a series of challenges and social upheavals there is the need for a justified faith and thus a visit to Thomas Aquinas to offer solution to our challenges (Liddy, 2013). In fact, according to Doyle, 2007, Thomistic philosophy was a fitting in approach for the US Catholic schools in the early 1960s since it acknowledged tradition and embraced modernity without conflicts.

The study therefore investigated on the Thomas Aquinas philosophical ideas and their implications in contemporary education in Kenya with a view to rearticulate Catholic philosophy of education's role in addressing the contemporary ethical challenges in Kenya's schools.

\subsection{Problem of the study}

Education for responsible citizenry has always prioritized Virtues as core to integrating man into the society. The use of social institutions to orient man towards self-consciousness has been ongoing since their inception. In addition, the inclusion of Christian Religious Education in the curriculum as a means of providing intellectual training towards responsible citizenry, due to extremes among the inter denominations for instance radicalization of the youths, increased arsons and attacks in secondary schools, use of drugs and contraceptives etc. provoke the need for a critical interrogation of education and training that facilitates responsible citizenry and that promotes human dignity and discovery of the creator, God. The study, therefore, was tasked with examining the critical aspects in the education 
theory of Thomas Aquinas, and how it has been integrated in the Kenya's education system towards addressing societal evils towards responsible citizenry.

\subsection{Research objectives: The study is tasked to:}

a. Critically examine salient features of Thomistic philosophy

b. Establish whether Thomas Aquinas' education Theory can facilitate realization of Responsible citizens in Kenya

\subsection{Methodology}

This study adopts the analytic method whose major task is to breakdown complex entities and tries to unfold the clarity of the whole and the functions of the parts (Kauka, 2018). Philosophical analysis is purely a rational and abstract method, thus qualitative literature was accessed to facilitate the research as opposed to empirical research that demands quantitative analysis. The method fits this study because it's a purely a philosophical research.

\section{THEORETICAL FRAMEWORK}

\subsection{Dialectical materialism}

This embraces human capital orientation that treats man as a continuous challenge in the society as investigated by the scientific fields (Bugiulescu, 2018). This theory is also known as Marxist theory because it was proposed by Karl Marx (Kiruki, 2004). The understanding of the society according to Marxists is that in the society there is competition for material resources and wealth as the main cause of conflict. The social classes emanating from possession of property creates antagonism between them, one of which becomes the dominant class called the bourgeoisie. The bourgeoisie controls both the means of material production and the ideas of the epoch. In essence state machinery, state ideology and even religion are used to maintain the status quo. (Kiruki, 2004) The revolution brought as a result of class struggles always elevates the bourgeoisie as the victors thus making the proletariat more vulnerable and in need of the jobs. Despite man being a social being as described by Aristotle, his rational faculties when empowered can contemplate the reality as such and thus orient man towards freedom, consciousness and holistic growth (Bugiulescu, 2018).

\subsection{Moral virtue Theory}

Grounded in a philosophical tradition, the theory treats man as a rational, conscious, free being and created by God to know and serve him eternally. Thus, by nature man is religious and is tuned towards the infinite being (Stoker, 2000). The church as a moral agent is an indispensable organ that human beings realize the friendship and dependence on the infinite being. The overdependence on science and self-limits man in realizing the potentials of the infinite Being. Thus, through the person of Christ, the second person of the Trinity all humanity has been perfected for eternity (Bugiulescu, 2018) and therefore sanctified for the kingdom of God. Through rational faculties human beings are able to work for the good and be Good by the grace given unto them. This theory heavily relies on character formation and training through Pupil

\section{THOMAS AQUINAS}

Thomas was born in Aquino from a noble family with relations with the royals like kings of Aragón. At the age of fourteen, he became a student of the liberal arts at the imperial studium generale in Naples, a school that later became part of the University of Bologna, which has commonly been viewed as the oldest secular university in Europe. Thomas being an avid scholar of the antiquity, was greatly influenced by the works of Aristotle, Averroes and Avicenna (Jānis, 2020)

Thomas Aquinas became profoundly engaged in the heated debate about whether and how the metaphysical, ethical, psychological, and natural scientific writings of Aristotle that had been recovered during the twelfth and thirteenth centuries should be integrated in the curriculum and what implications could they bring in reformation process (Brock, 2015).According to Kiruki (2004) the Dominican Albertus Magnus of Cologne, had a particular influence on Thomas Aquinas's views in this regard and that is why Philosophy was thus conceptualized as handmaid of Theology and equally the state to the church in matters of the infinite (Brock, 2015).

According to Brock (2015), Thomas Aquinas was an exemplary author who is alleged dictated to three sectaries at a go. He prepared a commentary on the Sentences of Peter Lombard (1252-1256), Compedium Theologiae 1273, Summa Contra Gentiles (1259-1264), Summa Thelogiae (1265-1273), commentaries on the works of Aristotle and other renown philosophers and on books of the Holy Bible, Treatises, Translations, lectures, debates, sermons, hymns, poems on a wide range of philosophical and theological themes.

\subsection{Thomas Aquinas Philosophy}

\subsubsection{Classical Metaphysics}

As already mentioned, Thomas Aquinas was greatly influenced by Aristotelian metaphysics. It has also been remarked by contemporary scholars that if Augustine was the Plato of the Middle Ages, then Thomas Aquinas is the Aristotle (Kiruki, 2004). In this section therefore, the principles of act and potency, entity and essence, principle of participation shall be analyzed.

\section{Act and potency}

In chapter iv of entity and Essence Thomas clearly defines act as a form without matter and this form varies in separate substance. Pure actuality is only a character of the Supreme Being whereas the intelligences have form but since they can be caused (created) their act is not pure. Finally the matter and form in the corporeal beings makes them composite and because of matter being an individuation principle their exist the idea of plurality thus need for species and genus and thus difference. 
In the process of becoming, an item or an object shows two states of being. One that shows the possibility of becoming (potentiality) and another attained state of being (actuality) (Collins, 1990). In addition, an object can't have the two states at the same time since this is against the principle of non contradiction. Act therefore signifies a perfection that is inhered within being, thus no limitations or no error, difference or multiplicity and on the other hand potency may be described as a relative state of non being (Aquinas T. , A Translation by Robert T.Miller On Being and Essence(1997)).

The real distinction between act and potency is not a distinction of separate entities but of two principles of the same reality. Thus Thomas Aquinas uses this principle in dividing real being with respect to perfection. According to Thomas Aquinas, God "IS" a pure actuality, no potency in Him, angels are actualities, human being is in a mixed potency and a mixed actuality whereas universe and rocks have pure potency with a limiting principle itself inhered in them. Thus act and potency give the degree of being in the hierarchy of existence (Aquinas T. , A Translation by Robert T.Miller On Being and Essence(1997))

\subsubsection{Essence and Existence}

Aristotle's hylemorphism laid the foundation of explaining the essence and existence of beings.Hylemorphism is a theory of act and potency that is applied to specific order of essences and the term etymologically its derived from the Greek words for matter (hyle) and form (morphe) (Kiruki, 2004).Essence is the whatness or the form of being whereas the existence of being refers to the act of being. In search for the subject of discussion, Thomas Aquinas identifies essence and existence to be the same thing in God (Aquinas T. , A Translation by Robert T.Miller On Being and Essence(1997)).

In the Entity and Essence, Thomas highlights the ways in which the essences vary in the separate substances. God being a perfection that ever existed, the substance of God is his essence and it is the existence itself. For the created intelligences, since their essences are without matter and existence is received or caused, they are finite beings. Thus existence and essence differ in finite beings. For the human being, the existence and essence are separate entities due to the separate relationship between matter and form, body and spirit and existence in this case is individuated by the body.

\subsubsection{Causality}

Discussion on the concept of causality in Aristotelian Metaphysics, the material, formal, efficient and final causes can be traced to the process of becoming of an object. However, there has to be the cause of all causes "unmoved mover" in Aristotle's own terms. According to Kiruki (2004), the notion of the unmoved mover had great influence on all medieval philosophers. Since God was the pure actuality and the cause of all creation, his existence and essence is one and the same thing (Aquinas.T 1247-)-God can cause the existence of intelligible and man. The plurality that there exists among the intelligible and man is as a result of the finitude that their substances have.

Man possesses rationality that allows active and passive intellect to create and recreate and this allows man to participate in the causality of God as a second efficient cause of potency being moved in act. Thomas Aquinas treated man as a synthesis and placed him noble above all creation because of the intellect that makes him reflect on the source of all beings, God (Bugiulescu, 2018).

\subsubsection{Classical Epistemology}

Man as a rational being and able to reflect on the deity, Thomas Aquinas views the human intellect void of innate ideas but with a potentiality of receiving concepts The human intellect thus through the passive intellect sense knowledge is availed and by use of the active intellect the universal is abstracted from the particulars. The human mind thus has the ability to abstract concepts from the existing or known items and thus relate them and form new concepts. And since there exists different items or objects due to the principle of individuation, the plurality of items creates the need classify them under species and genus and thus why the mind can retain the differences and commonness of objects.

The process of knowing therefore originates from the impressions that are availed through senses. The sense perception availed to the mind enables a rational soul to abstract intelligible species from the sensible objects. However, immaterial things which are not objects of sensation, human intellect is does not and cannot by its own ability apprehend God and spirit directly because of lack of positive content about them. The only way we come to know them is through the negative way (Via negative) thus through denial of the characteristics well known to sensible objects or by analogy (summa 1a,84,7).

According to Thomas Aquinas, there are two major ways of coming to know. First and foremost Discovery: A method that disposes human reason by itself to reach knowledge of unknown things and grasping their essences. Secondly, Learning by instructions: This method demands for the second party that is vast in the known elements that are not yet revealed to the pupil and thus with the aid of the Teacher, the pupil is introduced, guided and ignited in his own way to use rational faculties to grasp the essences of tings being taught (Aquinas T. , Truth Translated by R. W. Mulligan. 3 vols. Chicago: Regnery, 1952).

\subsubsection{Classical Ethics}

The pagan belief and medieval approach to reality was fading away with the upcoming of the Faith and reason trend. Thomas Aquinas age is scholastic because of such legacy of advocating intellectual formation that directed all spheres of life. Thomas in orienting man towards the ideal, intellectual formation is key and must be directed towards the Good, who is God Summa Contra Gentiles 114-138 x libros ethicorun questions Disputetea de malo). 
Moral soundness thus was only possible when man had to orient his voluntary actions towards knowing God and seeking the common good. Thus Thomas Aquinas views the moral good and evil in terms of accord and discord to divine law as revealed in scriptures and interpreted in the Christian tradition. Thomas Aquinas ethical theory is classified by scholars as natural law theory (Kiruki, 2004).Basing on the Nicomachean Ethics of Aristotle, he developed a Eudaemonological and teleological standpoint in the analysis of human conduct and acquisition of virtues. All human beings are wired naturally to adhere to the law (Kiruki, 2004).

Human being a rational being was given the conscience which is a tool for use in deciding to execute or not execute acts. According to Thomas Aquinas, there exist Voluntary acts and involuntary actions. Man by his rationality has the ability to chose from a series of options guided by the intellect and for a voluntary action to be performed, there must be sufficient knowledge about the act generating the good or contributing to the attainment of the common good (Bunum Commune) Summa Theologica I-II 90, A.4c.

\subsubsection{Thomas on Virtues}

According to Thomas virtue is a perfection of power that finds its justification in an action. Human being by nature engaging rational powers they usually determine actions and because of the finitude nature, human rational powers are indeterminate to act in a uni- directional way thus a series of acts are experienced. Through habitual training thus rational powers can be oriented towards a uniformed mode of action (Summa Theologica Ia-IIae, Q. 55, A. 1, c).

Virtues being mere dispositions to act in accordance to a particular, stable and adequate manner are modifications of personality and thus can be acquired through habitual training.This thomistic view is in line with the Aristotelian ethical notion. In the light of the training in virtues, there are five intellectual virtues where three are speculative and two are practical. The speculative ones are: understanding, Science and Wisdom (Summa Theologica Ia-IIae, Q. 57, A. 2, c).

The practical Virtues are acquired when reason is rightly applied in doing things and executing actions. In other words, In order to do good, there is need by the human person to perfect the intellect in recognizing the truth (prudence) (Summa Theologica Ia-IIae, Q.57, A.4) and a perfection of the will seeking good (justice-Summa Theologica Ia-IIae, Q 58 A.3). Another necessary condition for doing good is the capacity for reasonable management of emotions so that, on the one hand, a person in a difficult situation is not overwhelmed by the desire of sensual pleasures by practicing temperance- Summa Theologica Ia-IIae, Q 141) and on the other hand, does not refrain from difficult challenges, especially when the journey towards the good involves suffering (fortitude- Summa Theologica Ia-IIae, Q 123).

Finally, Thomas talks of another type of virtue that are God given through grace: Theological virtues. First and foremost
Faith in God (Summa Theologica Ia-IIae, Q 4 A. 4), Hope (Summa Theologica Ia-IIae, Q17 A.5), and charity (Summa Theologica Ia-IIae, Q 23.A.4).

\subsubsection{Thomas on Religion}

Religion has been a term during our time ignited varied views and tensions towards a smooth existence and raising of the young in virtue. In the light of Thomas Aquinas Summa Theologica, religion is elaborated as an element that is not equated to sanctity or the divine itself. According to Thomas, since the time of Cicero etymologically man has been said to be religious ab initio from "religio" because he often ponders over or "religit" reads again the things that pertain to the worship of God (Summa Theologica Ia-IIae, Q 80.A.2).

Religion thus objectively directs man to the sole worship of God alone and the main acts include adoration and sacrifice to the supreme being any other external acts are secondary and not immediate in the worship of God (Summa Theologica IaIIae, Q 80.A.7.)

\section{CATHOLIC CHURCH AND EDUCATION IN KENYA}

Kenya as country adopted the 8.4.4 education system in 1989 for preparing a self-sufficient, responsible citizen. This is highlighted in the national goals of education by the Kenya Institute of Education syllabuses (Kenya Institute of Education (KIE) , 2013). Scholars have criticized the process of change of education systems in Kenya to be void of consultative process and need based on societal issues (Muricho,P.,\& Chang'ach,J., 2013). Political interests have taken over the entire education process and thus limiting any other social institution to influence education process (Amutabi, 2003).However, the philosophical, rational and conscious roots of man are always grounded on a religious footing (Mbithi, 1988), (Fatih, 2018) Thus by nature man has to discover the divine being.

Based on the Ideal of Thomas Aquinas on the possibility of the human being to be taught as presented in his Treatise $D e$ Magistro, the early missionaries developed centres for the training of teachers with a sound moral shaped around the imitation of Christ the model teacher of the Gospel. Thus the teacher was to orient the pupils towards the knowledge of God. As a cause of Knowledge, The teacher was to be prepared in the Christ centered training to facilitate learning.

Secondly, Discipline has been emphasized by the catholic tradition, for the learner to acquire true knowledge Virtues are to be acquired and practiced frequently. Prudence, justice, temperance and fortitude have taken the lead during the pandemic where the church has championed giving of alms, donations, volunteer service providers to refugee camps and regions hit by disasters i.e. floods, hunger etc. These practices have provided room for the church to affirm the presence of God in the suffering people. Thus, catholic institutions have provided both material and non-material items towards the needy and thus building a common body of Christ. 
Thirdly, the pastoral programmes have been opportunities for the young to discover the infinite, learn to read and contemplate the scripture in order to shape character in the learning environment. Morning and evening services, Holy Mass offered with specific intentions for the students has always introduced learners to a pious lifestyle towards the Transcendent Being.

\section{IMPLICATIONS THOMAS AQUINAS IDEAS TO EDUCATION AND TRAINING IN KENYA}

\subsection{Aims of Education}

The primary role of every student is to fall in love with the master. Discipleship as given by Thomas demands strict adherence to divine law and precepts of the Church. Scripture occupies a crucial place in the life of the pupil and thus the entire education and training process facilitates the knowing and discovery of God. Secondly, with God given Potentials, the Pupil is to serve humanity as given in the Gospels. The message of living the scripture demands responsibility and acts of mercy and charity thus emphasis laid on individual responsibility drives education practitioners to participate in community and societal development activities without reservations. Religion thus has external acts which model one towards virtue and thus through habitual training students can acquire them in their schools and learning environments (Summa Theologica Ia-IIae, Q 80).

With the imitation of Christ, the triumph over death at Calvary motivates the followers of the master to endure some pain for the sake of future joys. Character formation has always been a challenge and sometimes demands loss of friends, pains, sorrows but enduring them models one for future tragic situations.

\subsection{Curriculum}

The christocentric curriculum aims at orienting the whole person towards God the creator. Thus all activities are started by prayer and finished by prayer. This is a reconciliatory curriculum which gives hope to the hopeless and courage to the downhearted.

\subsubsection{Curriculum content}

Scripture takes the centre stage of the education and training process. Christian Religious Education (CRE) is a subject prepared to expose the student to the Old Testament and New Testament Books. This content is geared towards achieving the mission of orienting students towards self-transcendence and thus participating actively and consciously in the community.

\subsubsection{Teaching methods}

Thomas Aquinas believed that learning may be initiated by a teacher. Furthermore, he stresses that a good teacher must build his teaching on the gradual development of human nature. Indeed, a good teacher should anticipate and follow the sequence that the student himself would choose, if the option of making the decision was offered to him. Thomas Aquinas closely links this topic to the Aristotelian syllogism. He stresses, for example, that the presentation of the subject matter to be taught must be logical, precise, and lucid. Clarity is central to successful instruction. Moreover, he gives priority to the way in which the teacher presents his material, which must be both effective and appealing to the mind.

Further recommendations include the use of a questionanswer sequence in discussing topics, the review of historic solutions of problems, the use of symbols as tools for instruction in particularly unfamiliar things or ideas, and the linking up of the subject under discussion with as many other subjects as possible. The emphasis here is on "possible," because one should not risk confusing the student.

\subsubsection{Teacher-student relationship}

First, in order for learning to take place, students must face a problem that arouses their interest and about which they are willing to learn. The teacher should then facilitate the students' learning activities and guide them to the knowledge of truth. Truth, according to Thomas Aquinas, exists in the mind of God as well as in things (that is, the embodied "ideas of God,") and, finally, in the mind of the human being who, by abstracting and interpreting the meaning of the universe, comes to know God. Second, the teacher must have perfected his own knowledge. Only then can the teacher truly help the students organize their experience and knowledge, and instruct them further. Third, the teacher must appreciate the special significance of "method" for education. He must know that the reflective processes leading the student to knowledge acquisition determine the method of instruction. Fourth, the teacher must respect the students' freedom in learning. Still, he should help them to avoid errors and their oftendiscouraging effects. Thus by often discouraging them to avoid errors the teacher serves them as a disciplinarian and character formator.

\subsubsection{Learning Environment}

Learning under a catholic tradition demands participation in daily masses and the practice catholic faith especially keeping the holy days and sacraments. Emphasis of community living orients one to find fraternal promotion and correction towards character formation and training that accepts and willingly participates in community growth. A reflective, conducive environment thus must allow contemplation and above all discovery of the divine in all activities.

\section{CONCLUSION AND RECOMMENDATION}

St Thomas Aquinas education theory is loaded with crucial aspects for instance: act and potency, moral theory, divine law and relevance of virtues, epistemology, entity and essence and finally role of religion in character formation. In the light of these ideas, the study can be summarized as follows:

First and foremost, man can only be discussed objectively when the study does not compartmentalizes man's being. 
Human beings by nature are religious and thus this does not rule out them being social, Psychological and rational powers. Man as a creature by God has always engaged the rational faculties in the search of the creator and this is the core business of man on earth. Thus it is of necessity, the Ministry of Education to employ enough Chaplains in secondary schools and institutions of higher learning to facilitate religious education and pastoral programmes.

Secondly, education and training in virtues involves intellectual formation and training. Availing of content for religious value can be picked from the scriptures, daily external and internal activities of religion: adoration and sacrifices. The study therefore recommends for the employment of enough Religious studies teacher at all levels of 8.4.4 to facilitate curriculum implementation and assessment on the attainment of the religious values.

Thirdly, training in virtues is a continuous process and to be totally pure: sanctified is not easy here on earth and may be in the world to come. Perfection is only reserved for God and by religious acts faithful contemplate perfection in the world to come. The Government to control extreme religious beliefs, customs and practices in order to facilitate smooth practice of religion that do not orient the young to extremes i.e. assassinations, radicalization and illuminatism.

\section{REFERENCES}

[1] Ada.M.J., A. \&. (2012). Saint Thomas Aquinas Theories on Man, Society, Government, law and Applicabilityof these ideas in the Administration of Nigerian Secondary Schools. World J Young Researchers, Issue 2 vol (5) pp 65-69.

[2] Amutabi, M. (2003). Political interference in the running of education in post-independence Kenya:A critical retrospection. International Journal of Education Development, 23(2), 127-144.

[3] Aquinas, T. (n.d.). A Translation by Robert T.Miller On Being and Essence (1997). New York: www.Abika.com.

[4] Aquinas, T. (n.d.). Summa Theologica Benziger Bros. edition. Ohio: Translated by Fathers of the English Dominican Province 1947 (Original work completed 1259-1264).

[5] Aquinas, T. (n.d.). Summary against the gentiles (A. Pegis, J. Anderson, V. Bourke, \& C. O'Neill,. Notre Dame: IN: University of Notre Dame Press.1975 (Original work completed 1259-1264).

[6] Aquinas, T. (n.d.). Truth Translated by R. W. Mulligan. 3 vols. Chicago: Regnery, 1952. Chicago: Regnery.

[7] Brock, S. L. (2015). The Philosophy of Saint Thomas Aquinas;A sketch. 199 West 8th Avenue, Suite 3, Eugene,: Cascade Books WIPF and STOCK Publishers.

[8] Bugiulescu, M. (2018). Man as a Religious, Rational,Free and Conscious Being. International Journal of Theology, Philosophy and Science, No. 2, Year 2 pp 5-16.

[9] Cheserek.G., \& Mugalavai,V. (2012). Challenges and Reforms facing Kenyan Education system in the 21st century:Integrating the principles of Vision 2030 and Constitution 2010. Journal of Emrging Trends in Educational Research and Policy Studies, 3(4), 471-478.

[10] Chowdhury, M. (2016). Emphasizing Morals, Values, Ethics, and Character Education In Science Education And Science Teaching.
The Malaysian Online Journal of Educational Science, Volume4 Issue 2 pp 1-16.

[11] Collins, P. M. (1990). Aristotle and the Philosophy of Intellectual education. The Irish Journal of Education, 62-88.

[12] Doyle, D. (2007). Thomas Aquinas:Intergrating Faith and Reason in Catholic Schools. Focus Section Catholic Education, pp 342356.

[13] Fatih, M. (2018). Values Education or Religious Education? An Alternative View of Religious Education in theSecular Age, the Case of Turkey. Education Science, pp 1-16.

[14] Gilson, E. (Gilson, E. (1994). The Christian philosophy of St. Thomas Aquinas (L. K. Shook, Trans.)). The Christian philosophy of St. Thomas Aquinas (L. K. Shook, Trans.). Notre. Notre Dame: IN: University of Notre Dame Press. (Original work published 1956).

[15] Jānis, T. O. (2020). Aquinas, education and the theory of illumination. Educational Philosophy and Theory, DOI: $10.1080 / 00131857.2020 .1768632$.

[16] Jarosław, H. (2020). Christian religious education and the development of moral virtues: a neo-Thomistic approach. British Journal of Religious Education, 42:4, 447-458.

[17] John, P. I. (1998). Fides et ratio [Faith and reason]. Washington, DC: United States Catholic Conference.

[18] Kauka, E. O. (2018). An Analysis of the Nexus of Existentialism in Education. International Journal of Research and Innovation in Social Science (IJRISS), Volume II, Issue XII,pp 228-232.

[19] KAYMAKCAN.R., \&. M. (2012). Values in the Curricula of Religious Education and Social Studies in Primary Schools in the Context ofLocal-Universal Dilemma*. Educational Sciences: Theory \& Practice, 12 (2) Supplementary Special Issue PP 15881591.

[20] Kenya Institute of Education (KIE) . (2013). Craft Certificate in Building Technology Syllabus and regulations. Nairobi: Kenya Institute of Curriculum Development.

[21] Kiruki, J. K. (2004). Introduction to Critical Thinking. Eldoret: Zapf Chancery Research Consultants and Publishers.

[22] Leo, X. (1879). Aeterni patris [On the restoration of Christian philosophy]. London: J. Donovan.

[23] Liddy, R. M. (2013). Bernard Lonergan on a Catholic Liberal Arts Education. Catholic Education: A Journal of Inquiry and Practice, pp 520-533.

[24] Mąkosa, P. (2020). St. John Paul II and Catholic education. A review of his teachings: an essay to inspire Catholic educators internationally. International Studies in Catholic Education, 12:2, 218-235, DOI: 10.1080/19422539.2020.1811006.

[25] Maritain, J. (Maritain, J. (1938). True humanism (M. Adamson, Trans.) ). True humanism (M. Adamson, Trans.) New York: Charles Scribner's Sons. New York: Charles Scribner's Sons.

[26] Mbithi, J. (1988). African Religions and Philosophy. Nairobi: Heinemann.

[27] Muricho,P.,\& Chang'ach,J. (2013). Education Reforms in Kenya for Innovation. International Journal of Humanities and Social Science, 3(9), 123-145.

[28] Niculescu R. M., \&. N. (2013). Religious education an important dimension of human's education. P r o c e d i a - S o c i a l a n d B e h a viora $1 \mathrm{~S}$ c i e n c e s, PP 338-342.

[29] Rashid, M. M. (2019). St. Thomas Aquinas and the Development of Natural Law in Economic Thought. Munich Personal RePEc Archive, https://mpra.ub.uni-muenchen.de/93435/ PP 1-17.

[30] Stoker, W. (2000). Are Human Beings Religious by Nature? Schleiermacher's Generic View of Religion and the Contemporary Pluralistic, Secular Culture. International Journal in Philosophy and Theology, 51-75.

[31] Towns, E. L. (1975). A History of Religious Educators Books. Paper 24. http://digitalcommons.liberty.edu/towns books/24. 